\title{
Az EURÓPAI FELSŐOKTATÁSI TÉRSÉG LÉTREHOZÁSA MINT AZ EURÓPAI UNIÓ FELSŐOKTATÁS-POLITIKÁJÁNAK KÖZPONTI ELEME
}

\author{
HRUBOS ILDIKÓ
}

Budapesti Corvinus Egyetem

\begin{abstract}
Az európai felsőoktatási térség létrehozása az integrációs folyamat döntő jelentőségű eleme, amiben kezdettől fogva megjelent két vonulat. Az egyik az Európai Bizottság, amely a politikai, gazdasági, szabályozási vonulatot képviseli, kezdeményezi és finanszírozza a döntő fontosságú lépéseket. A másik a felsőoktatási intézmények világa, és annak letéteményese az Európai Egyetemi Szövetség, az akadémiai értékek és az európai hagyományok őrzője. A tanulmány e két erőközpont összjátékát mutatja be, a térség egészére és ebben a magyar felsőoktatásra vonatkozóan. Időben követi a Bologna-reform megvalósításának lépéseit, és felhívja a figyelmet annak ellentmondásos vonatkozásaira (az európai, a nemzeti és az intézményi szint összehangolásának nehézségeire, a konvergencia és a széttartás együttes megjelenésére, az állam vagy piac dilemmára).
\end{abstract}

Kulcsszavak» harmonizálás, differenciálódás, elismerés, aszimmetria

The creation of the European Higher Education Area is a defining element of the integration process, in which two powers appeared from the beginning. One of them is the European Commission, which represents the political, economic and regulatory power initiates and finances critically important steps. The other is the world of higher education institutions and their representative, the European University Association, which is the custodian of preserving academic values and European traditions. The study presents the interplay of these two power centers, as they relate to the entirety of the region, and within that Hungarian higher education. It follows the steps of the implementation of the Bologna-reform in time, and points out its contradictory aspects (the difficulties in harmonizing the European, national and institutional levels, the simultaneous appearance of convergence and divergence, the state or market dilemma).

Keywords: harmonization, differentiation, recognition, asymmetry

Levelező szerző: Hrubos Ildikó, 1115 Budapest, Etele út 50/A, VII. em. 43.

E-mail: ildiko.hrubos@uni-corvinus.hu 


\section{Bevezetés $^{1}$}

$\mathrm{A}$ felsőoktatás kérdése kezdettől az európai integrációs folyamat hangsúlyos része volt, és szerepe az 1980-as évektől kezdődően egyre erőteljesebben jelentkezett. Ehhez hathatós hátszelet adott a szovjet tömb várható, majd tényleges felbomlása, és ennek kapcsán az Európai Unió (EU) bővülésének kilátása. A berlini fal leomlása után értelemszerűen felmerült az európai felsőoktatás, az európai kultúra egyik döntő eleme egységes kezelésének kérdése. Ezen a területen jól láthatóvá vált a két, egymást részben átfedő vonulat kibontakozása. $\mathrm{Az}$ EU a saját (egyre bővülő) földrajzi területén elsősorban gazdasági és politikai vonatkozások figyelembevételével kezdte el érvényesíteni saját felsőoktatás-politikáját, az akadémiai világ Európa egészében gondolkodva indította meg a felsőoktatási együttműködés kiépítését. A folyamatok időben szinte párhuzamosan haladtak és nyilvánvalóan erősítették egymást.

Az Európai Bizottság (EB) kezdeményezésére 1988-tól fokozatosan kidolgozták az Európai Kredit Átviteli Rendszert (European Credit Transfer System - ECTS).

1988-ban az Európa Tanácsnak és az Európai Egyetemek Rektori Konferenciájának (az Európai Egyetemi Szövetség elődintézményének) a kezdeményezésére európai rektorok (a nyugati és a keleti tömbből egyaránt) kibocsátották az európai egyetemek Magna Chartáját, amelyben rögzítették azokat a hagyományos és modern értékeket, amelyeket kívánatos lenne egységesen követniük. ${ }^{2} \mathrm{~A} z$ Európai Bizottság ugyanakkor létrehozta az Erasmus-programot, azzal a feladattal, hogy gyakorlati (szervezési és finanszírozási) keretet adjon az egyik fontos európai értéknek, a határokat átívelő hallgatói és tanári mobilitásnak.

1994-ben az EB, az Európai Tanács és az UNESCO európai regionális szervezete elindította az oklevélmelléklet rendszerének megalkotását, amely dokumentum lehetővé teszi az egyéni diplomák értelmezését.

1997-ben az Európa Tanács és az UNESCO európai regionális szervezete kezdeményezésére aláírták a Lisszaboni Egyezményt a felsőoktatási képesítéseknek az európai régióban történő elismeréséről. Ez fontos jogi lépés volt, ami lehetővé tette a hallgatók és a munkavállalók határokat átívelő mobilitását. Innen már csak egy lépés volt annak felismerése, hogy az elismertetésnek alapvető feltétele a felsőoktatás kereteinek összehangolása.

1998-ban az Egyesült Királyság, Franciaország, Olaszország és Németország oktatási miniszterei Párizsban aláírták a Sorbonne Nyilatkozatot, bejelentették szándékukat az Európai Felsőoktatási Térség (EFT) létrehozására, és csatlakozásra hívták meg Európa országait.

1999-ben összesen 29 ország (köztük Magyarország) oktatási miniszterei aláírták a Bolognai Nyilatkozatot és ezzel megindult az európai felsőoktatási reform. (Ezután fokozatosan csatlakoztak hozzá további országok, úgyhogy 2015-től már 48 tagja van az egyezménynek, lényegében minden európai ország.) (Hrubos 2016.)

A kutatás az EFOP 3.4.5. projekt keretében zajlott.

http://www.magna-charta.org/magna-charta-universitatum/read-the-magna-charta/the-magna-charta [Letöltve: 2019. 03. 05.] 
A tanulmány annak a folyamatnak a fó állomásairól, elért eredményeiről és vitatott, nyitott kérdéseiről szól, melyek alapvetően határozták meg a térség felsőoktatásának átalakulását. Ez alkalmat ad arra, hogy a magyar felsőoktatásban az elmúlt 15 évben történteket ebben a nemzetközi környezetben tudjuk értelmezni. A reform indítékairól és a megvalósítás szervezeti kereteiről szóló fejezet után az időbeliséget követve az első, majd a második évtized (szakasz) főbb történéseit mutatja be és értékeli. Egy általánosabb szintű megközelítéssel élő, néhány összefoglaló tanulsággal foglalkozó fejezet zárja a tanulmányt.

\section{A reform indítékai és a bevezetés irányítási-szervezeti keretei}

A reform megindításának alapvető indítéka gazdasági jellegű volt, az európai gazdaság fellendítését kívánta szolgálni, a magasan képzett munkaerő akadálymentes mozgásának lehetővé tételével. A várakozások szerint a képzési szerkezet átalakítása lehetővé teszi majd a tömeges és az elit képzés együttes megvalósítását. Nem fogalmazódott meg explicit formában, de köztudott volt, az alapítók elsősorban egy európai elit kinevelését akarták megvalósítani, amelynek müveltsége, szaktudása, kultúrája, identitása, lojalitása európai. Így szakmai karrierje során bárhol használható, természetes számára a határokat átívelő mobilitás, és mindenütt az európai szempontok vezérlik (akkor is, ha időnként saját hazájában dolgozik). A diplomás tömegek nagyobb része továbbra is a hazai munkaerőpiacon fog tevékenykedni, de jó, ha számukra is lehetővé válik a külföldi munkavállalás.

A Bolognai Nyilatkozat hat pontban foglalja össze a feladatokat. Közülük a két legátfogóbb és legnagyobb, leglátványosabb a könnyen érthető és összehasonlítható fokozatok rendszerének bevezetése, valamint a két (utóbb három) cikluson alapuló képzési struktúra kialakítása. Három pont a fentiek müködését szolgáló eszközök (oklevélmelléklet, kredit átviteli rendszer, minőségbiztosítás) müködtetését írja elő. Külön pont utal az egyetemi polgárok mobilitásának támogatására, az egyenlő esélyek biztosítása mellett. Végül egy tartalmi kérdés zárja a sort: az európai vonatkozások beépítése a felsőoktatásba. ${ }^{3}$

Kiépült a reform megvalósítását irányító európai szintű szervezeti rendszer. A legfelső stratégiaalkotó és döntéshozó testület az oktatásért (felsőoktatásért) felelős miniszterek konferenciája. Ez a testület az első 10 éves szakaszban kétévente ülésezett (majd a második szakaszban háromévente, és a tervek szerint a 2020-tól kezdődő harmadik szakaszban visszatérnek a kétévenkénti rendszerhez). A végrehajtás irányítását a Nemzetközi Bologna Csoport (Bologna Followup Group) végzi, amely a két miniszteri konferencia között döntéshozó hatáskörrel rendelkezik. Ez is igen népes testület. Szavazati joggal rendelkeznek a tagországok oktatási kormányzatának képviselői (ők általában a nemzeti Bologna-bizottságok vezetői, így biztosítják a kapcsolatot a tagországok szintjével). Ugyanilyen joggal rendelkezik még egy tag, mégpedig az EB képviselője. Szervezeti értelemben ez az a pont, ahol az EU megjelenik a reformfolyamatban (egyébként az EB és az Európa Tanács 2001-től vesz részt a projektben, leszámítva az előkészítő szakaszt). Vannak megfigyelői joggal rendelkező tagok, akik a társadalom és a felsőoktatás érdekhordozóinak széles körét jelenítik meg (az ún. E4-ek: az Európai Egyetemi

3 https://www.eurashe.eu/library/bologna_1999_bologna-declaration-pdf/ [Letöltve: 2019. 02. 16.] 
Szövetség [EUA], az Európai - nem egyetemi - Felsőoktatási Intézmények Szövetsége [EURASHE], az Európai Hallgatói Szövetség [ESU] és az Európai Minőségbiztosítási Szövetség [ENQA], továbbá az UNESCO Európai Felsőoktatási Központja, az Európai Munkaadók Szövetsége és az Oktatási Internacionálé Páneurópai Szervezete). Meghatározó szerepet az E4-ek játszanak, amely szervezetek rendszeres adatgyüjtéseket, vizsgálatokat végeznek és a miniszteri konferenciák előtt értékelő dokumentumokat készítenek. A Nemzetközi Bologna Csoport sokféle szakmai elemző munkát végez az általa felkért munkacsoportok útján, amelynek tagjait szakmai (esetleg regionális) szempontok alapján jelölik ki. Igen széles és összetett tehát az a kör, amelynek hangja megjelenik a reform irányításában. Fontos vonás a szakértői elem megjelenése, ami ellensúlyozza az alapvetően kormányzati jelleget. Hiányzik viszont az „igazi profeszszori hang", a felsőoktatásban meghatározó szerepet játszók, a nagy tudású, gyakorlati oktató-kutató munkát végzők hangja, akik nem töltenek be formális vezető szerepet. (Hrubos 2011.)

A reformot eredetileg tízéves időtartamúra tervezték, de már az első öt év után kiderült, hogy nem fog teljesülni az elképzelés, és szükség lesz egy második szakaszra is. Az első szakasz megindította az eredeti, hat pontban rögzített feladatok elvégzését, a másodikban a finomításra, az időközben felmerült új igények és szempontok szerinti korrekciókra került sor. A 20 éves számvetésre 2020-ban kerül sor, és várható, hogy egy újabb évtizedről fognak dönteni a miniszterek.

\section{Az első 10 év}

Jelen keretek között arra lehet vállalkozni, hogy a döntő elemnek mondható témát járjuk körül részletesebben, néhány fontosabb továbbit pedig tömören, utalásszerủen.

\section{A többszintü képzési szerkezet megvalósitásának modelljei}

A fenti megfontolásból a képzési szerkezet harmonizálásának témáját célszerű elemzésre kiválasztani, egyrészt meghatározó szerepe okán, másrészt azért, mert az abban történtek következményei jellemzően megjelentek a megvalósítás más területein is. A reform megálmodói abból a meggondolásból indultak ki, hogy a megvalósítandó közös modell az ún. lineáris (többlépcsős) modell legyen, mivel az képes leghatékonyabban megoldani ugyanazon rendszerben a tömeges és az elitképzést. Az amerikai párhuzam igazán kézenfekvő. Ezt az érvet azonban a reform ideológusai explicit és nyilvános formában szinte soha nem használták, tekintettel arra, hogy hangsúlyozottan „európai modellt” kívántak alkotni, éppen Európa nagy versenytársával, az USA-val szemben. Ez az ellentmondás azonban kezdetektől fogva megterhelte a reform elfogadtatását a felsőoktatás szereplői körében.

Bár a képzési szerkezet harmonizálása volt az átfogó cél, az európai egyetem három történelmi modelljének (tradicionális brit, humboldti, napóleoni) hatása egyértelmüen megjelent a megvalósítás során. Az Egyesült Királyságban nem okozott nagyobb gondot az átalakítás, mivel ott már jó ideje gyakorlat volt az egyetemeken a két, egymásra épülő fokozat rendszere (BA/BSc - MA/MSc). Kisebb korrekciókra volt csak szükség. Nagy megrázkódtatást okozott viszont a „humboldi Európában”, az ún. duális modell országaiban, ahol a nagy hallgatói létszámexpanzió során a felsőoktatás részeként kiépült az egye- 
temi szektor mellett a föiskolai (Fachhochschule, HBO stb.) szektor, amelyek tartalmilag nem kapcsolódnak egymáshoz, lényegük szerint más-más, az akadémiai, illetve a professzionális képzés megjelenítői. Erre a hagyományra építve itt a Bologna-áttérés azt jelentette, hogy megvalósult az egymásra épülő fokozatok rendszere, de két külön szektorban, amelyek között lehetséges az átmenet. Az egyetem mellett létrejött az alkalmazott tudományok egyeteme intézménytípus, a korábbi főiskolák átalakításával. A „napóleoni Európában" nem a duális rendszerről a lineárisra való átmenet volt a legnagyobb akadály, hanem az egyetemek egyeduralma (nem volt és ma sincs nagy méretü és ellenpontként is funkcionáló, professzionális képzést folytató szektor). Az egyetemek nehezen mozdultak el az osztott képzés felé, nem is tudták igazán jól elkülöníteni a BA/BSc és MA/MSc fokozat programjának tartalmát. Van, ahol a professzionális képzést az egyetemen belül próbálják megoldani úgy, hogy a $\mathrm{BA} / \mathrm{BSc}$ programoknak két változatát hirdetik meg (akadémiai és professzionális). A tapasztalat az, hogy népszerúek a professzionális képzések, az akadémiai vonulat pedig világos funkció és csökkenő hallgatói érdeklődés következtében kezdett kiüresedni. Máshol (pl. Olaszországban) az egyetemek továbbra is az akadémiai típusú képzésre vállalkoznak (a korábbi 5 éves programokat 3+2-re bontották szét), de a munkaerőpiacra csak ezt kiegészítő, általában az egyetemen kívüli intézményben történő szakmai képzés után lehet reálisan kilépni. Mindennek messzemenő következményei vannak pl. a BA/BSc és az MA/MSc fokozat misszióját, egymáshoz való kapcsolódását illetően és más, gyakorlatias kérdésekben.

Így már a kezdet kezdetén a négy alapító tag (a Sorbonne Nyilatkozat aláírói) négyféle módon oldották meg az egymásra épülő fokozatok szerinti képzési szerkezetet, ami természetesen hatott a rendszer más elemeire is. Ez alapul szolgált más országok számára is a különböző megoldásokra, ezáltal a rendszer differenciálódására (a harmonizálás jelszava mellett...) (Hrubos 2010.)

A különböző képzési szintek programjainak időbeli hossza (valójában kreditértéke) nem volt EFT szintű egyeztetés tárgya, igen változatosan alakult. Ezek ugyan időközben valamelyest változtak, de a különbségek alapvetően megmaradtak. Érdemes áttekinteni a 2016/2017-es állapotot.

$B A / B S c$ a az országok felénél 180, harmadánál 240 kredit, a továbbiaknál 210 kredit (3, 4, 3,5 év). (Vita folyik arról, hogy a programokat egységesen 4 évesre kellene beállítani, mivel a 3 év nem elegendő a többféle funkció ellátásához, a 3,5 éves pedig sok szervezési gondot okoz. Érv lehet az is, hogy a világ más régióiban a 4 éves forma terjedt el - amerikai minta alapján -, tehát a globálissá váló felsőoktatásba való bekapcsolódást az tudná segíteni. Az érintett kormányzatok azonban általában nem kívánnak foglalkozni a kérdéssel, legalábbis az általános áttéréssel, a pénzügyi következményekre való tekintettel.)

$M A / M S c$ : alapesetben 120 kredit (két év), de elterjedtek más megoldások is $(60,75$, 90 kredit).

Rövid ciklusú képzések: alapesetben 120 kredit (két év). Az országok felében van ilyen, ebből 18 országban része a felsőoktatásnak (Magyarország közéjük tartozik).

(A PhD-képzések változatos megoldásokkal müködnek.)

A Bologna-rendszeren kívüli (ún. osztatlan) képzések szinte minden országban vannak, országonként eltérő súllyal (Magyarország a középmezőnyben, a 10-20\%-os csoportban van, de Svédországban 30\%). (The European Higher Education Areain 2018: 96-112.) 


\section{A „magyar Bologna”}

Kelet-Közép-Európa országai sajátos, különösen nehéz helyzetbe kerültek a Bolognaprojekt során. Ebben a térségben több reform is egymásra torlódott. Az 1990-es politikai fordulat után indult meg a felsőoktatási hallgatói létszámexpanzió, sietve behozandó a lemaradást a nyugati országoktól, ahol ez már általában az 1960-as években elkezdődött. Meg kellett újítani a képzések tartalmát, a felsőoktatás igyekezett gyorsan lecserélni a korábban jellemző, az államszocialista rendszerben fogant koncepciókat és gyakorlatot. Néhány országban még az ország önállóvá válásából adódó feladatokkal is szembe kellett nézni (Csehország és Szlovákia szétválása, Jugoszlávia és Ukrajna esete), önálló felsőoktatási rendszert kellett létrehozni. Alighogy lépéseket tettek és eredményeket is elértek ezeken a területeken, 1999-től már megjelent egy egészen új kihívás. Bologna-csatlakozásuk nem volt kétséges, hiszen a többség esetében már folytak az Európai Unióba való belépés előkészületei, és az európai felsőoktatási reform elsők között való igenlése vonzónak, de legalábbis ajánlatosnak tünt. (Kozma-Rébay 2008.)

A magyar felsőoktatást különösen a szovjet modell lecserélése során követendő új modell megtalálásában zavarta meg Bologna. Eredetileg két, utóbb tévesnek bizonyuló elgondolás bontakozott ki. Az egyik tévedés történelmi volt: a II. világháború előtti, sikeres humboldti modellt kellene helyreállítani. Ezt a modellt azonban 1990-ben már túlhaladottá nyilvánították a nyugatiak, tekintettel arra, hogy nekik már korábban alkalmazkodniuk kellett a hatalmasra nőtt ágazat igényeihez, lehetőségeihez, úgyhogy jelentős reformokat hajtottak végre, megváltoztatva a modell lényegi vonásait. A másik tévedés földrajzinak mondható, mivel abból indult ki, hogy a 20. század leghatékonyabb felsőoktatási modellje az amerikai, tehát annak adaptálása lesz a megfelelő megoldás (a világbanki kölcsön tárgyalások során már korábban felmerült ez a lehetőség). Európában azonban akkorra már előtérbe került az európai kultúra, az európai hagyományok őrzésének elsőbbsége és az integráció.

A biztos és használható történelmi modell hiánya odavezetett, hogy a Bologna-reform szinte görcsös igyekezettel, a hazai tradíciók figyelembevétele nélkül került bevezetésre. Ugyancsak a konkrét történelmi helyzetből, az utolérési igyekezetből adódott, hogy hasonlóan több országhoz - Magyarországon is össze próbálták kapcsolni a Bolognareformot más reformokkal abban a reményben, hogy ezzel nagyobb esélyre lehet számítani azok társadalmi, politikai elfogadására. Ez a stratégia sehol nem vált be, mi több, paradox hatást ért el. A különböző reformok kölcsönösen rontották egymás esélyeit. (Magyarországon az akadémiai és az intézményi reform időben párhuzamos kezelése jó példa erre.) Mindezek a körülmények akadályozták, késleltették a munka tényleges elkezdését. 2005-ben fogadták el azt a felsőoktatási törvényt, amely a reform jogi kereteit megadta (a legtöbb országban ez 2001-2003-ban történt meg). Az ezután következő sietség nem tett jót a reformnak, nem hagyott időt a tartalmi előkészítésre, a rugalmasabb, esetleg fokozatos bevezetésre (amit a nyugati országokban jellemzően megtettek). Ugyancsak európai összehasonlításban túl merev és egysíkú megoldások születtek. Nem került sor a teljes képzési szerkezet átgondolására az első fokozat, az alapképzés tanterveinek, tantárgyainak megtervezése és akkreditálása, majd bevezetése előtt. Ennek következtében későn derültek ki az esetleges tévedések, amelyek időben való korrigálására alig volt esély. 
Az egész régióra jellemző volt, hogy a reform csak a fokozatot adó képzésekkel foglalkozott, nem vett tudomást a más jellegü, kifejezetten szakmai képzésekről, az „akadémiai sodrás" hatotta át a folyamatot. (A felsőfokú szakképzés, a szakirányú továbbképzés hányatott sorsa Magyarországon beleillett ebbe a képbe.) A munkaerőpiaci kapcsolódás kérdése az indulásnál lényegében hiányzott a modellből. Először csak 2007-ben, a londoni miniszteri konferencián merült fel komolyabban. A hamarosan kitörő pénzügyi, gazdasági válság azonban igen drasztikus módon állította a figyelem előterébe, és a reform második szakaszában az egyik fő vizsgálati és elemzési téma lett. (Hrubos 2010.)

\section{Az ún. Bologna-eszközök megteremtése}

A képzési szerkezet fentiekben bemutatott változatossága és más jelentős eltérések következtében hamarosan kiderült, hogy a külföldön szerzett végzettségek, a külföldön töltött tanulmányi idő kölcsönös elismerése továbbtanulás vagy munkavállalás esetén nemcsak elméleti, hanem nagyon is gyakorlati kérdés. Ennek korrekt megvalósításához meg kell teremteni a megfelelő feltételeket, amelyeket összefoglalóan Bologna-eszközöknek neveznek.

A legradikálisabb megközelítés az volt, amikor 2007-ben az EB kezdeményezte az ún. Tuning programot, amelynek célja az volt, hogy az európai országokban egy-egy szakterületen folyó képzés összehasonlíthatóságát elősegítsék. A felkért szakértői csoportok először összehasonlították a vizsgált terület képzési programjait, majd megállapodtak egy közös európai törzsanyagban. A projektnek voltak bizonyos eredményei, de rendkívül munkaigényes volta, no meg az általa felvetett kényes szuverenitási kérdések következtében végül elsikkadt. (Derényi-Temesi 2008.)

A végzettségek elismerésekor alapvető akadálynak bizonyult, hogy az egyes európai országokban más-más képesítési rendszerek vannak érvényben a teljes képzési rendszer vonatkozásában, ezért a végzettségek nem hasonlíthatók össze. 2003-ban Bergenben az EFT miniszteri konferencia úgy döntött, hogy meg kell alkotni az európai képesítési keretrendszert (EKKR), ${ }^{4}$ ami meg is történt, majd 2005-ben, Berlinben a miniszterek elfogadták. A következő lépés az volt, hogy 2007-ben Londonban már arról döntöttek, hogy ennek alapján ki kell dolgozni a nemzeti képesítési keretrendszereket. Ezt megtámogatta a „másik vonulat”. 2008-ban az EB javaslatára az Európai Parlament ajánlást fogalmazott meg, amelyben felszólította a tagállamokat, hogy önkéntességi alapon 2012-ig dolgozzák ki az európai mintának megfelelő saját rendszerüket. Azonban máig nem fejeződött be a program, a határidőt folyton továbbtolják, különösen a tényleges bevezetést illetően. (Magyarország egyébként azon EFT-országok közé tartozik, ahol a befejező szakaszában van. Többnyire azon országok vették komolyan a munkát, amelyek egyúttal EU-tagok is). (The European Higher Education Areain 2018: 121-125.)

A közös modell alapján létrehozott képesítési keretrendszer (a második Bologna-eszköz) hatással van az oklevélmellékletre és más vonatkozásban a kreditrendszerre is (harmadik és negyedik Bologna-eszköz), amiket ennek megfelelően korrigálni kellett. Ezek a munkák is áthúzódtak a második szakaszra. Az oklevélmelléklet rendszerének korszerüsítését az Európa Tanács, az EB és az UNESCO kezdeményezte, az általuk felkért mun-

http://www.cedefop.europa.eu/hu/events-and-projects/projects/european-qualifications-framework-eqf [Letöltve: 2019. 02.16.] 
kabizottság 2015-18 között készítette el az új sablont. Ez már tartalmazza a dokumentum digitális formájának bevezetését. (Utóbb, 2018-ban a párizsi miniszteri konferencia fogadta el és tette közzé a megújított dokumentumot.) A kreditrendszer kulcskérdés, mivel egyrészt annak összetett funkciói vannak a felsőoktatásban az átláthatóság biztosításában, de kiépítése eltérően történt meg az egyes EFT-országokban. Ez erősen akadályozza a teljesítmények mérését és annak elismerését. Mindez nehezíti pl. a hallgatói mobilitást, a cserediákok sorsát, akik két, különböző jellegű kreditgyakorlatot használó ország között szeretnének mozogni. Fontos tartalmi kérdés a kredit értelmezése, az egyszerübbtől az összetettebbig egyaránt van példa: a skálán a kontaktórák számától a tanulási eredményeket és a hallgató egyéni munkaráfordítását is beszámító gyakorlat is van. A korszerűsítés trendje az összetett megoldás felé való elmozdulás. (Derényi-Temesi 2008.)

A Bologna-eszközök között a legnagyobb jelentőséggel a minőségbiztosítási rendszer kialakítása bírt (az ötödik eszköz). Letéteményese az Európai Felsőoktatási Minőségbiztosítási Szövetség (ENQA), amely kezdeményezte és megalkotta az európai minőségbiztosítás sztenderdjeit és irányelveit tartalmazó dokumentumot (European Standards and Guidelines - ESG). A miniszterek 2005-ben fogadták el. Az ENQA tagintézményei a tagállamok nemzeti akkreditációs ügynökségei, amelyek hitet tettek az ESG mellett, ezzel biztosítva az egységes követelmények betartását. 2008-ban jelentős fordulat történt, a Bologna-érdekhordozók és több tagország kormányzatának javaslatára létrejött az Európai Felsőoktatási Regiszter (EQAR) azzal a céllal, hogy kibővülhessen az ügynökségek köre, hogy ne csak a nemzeti minősítési ügynökségek vehessenek részt az akkreditációs folyamatban. A tervek szerint regisztert állítanak össze azon ügynökségekről, akik erre felhatalmazást kapnak egy szakérői körtől. A munkájukra igényt tartó kormányzatok elfogadják a döntésüket, hasonlóan, mint saját nemzeti ügynökségeikét. Ennek különösen akkor van jelentősége, ha közös programok akkreditálása (Joint Degree) történik, és a gyakorlatban alig oldható meg, hogy pl. négy ország akkreditációs ügynöksége egybehangzóan elfogadja a benyújtott tervezetet. Az EQAR rendszer áthidalja ezt a problémát. Nemzetközi nonprofit szervezetről van szó, amelynek alapító tagjai az E4-ek, továbbá az eredeti „Bologna-érdekhordozók” és azon kormányzatok képviselői, amelyek beléptek a rendszerbe. A megalakuláskor csak 19 EFT-ország lépett be a szervezetbe (Magyarország és más országok, főleg a volt államszocialista országok nem voltak köztük). A kimaradók várakozó állásponton voltak, mivel láttak bizonyos esélyt arra, hogy az EQAR képében megszületett az a nemzetek feletti hatóság, amely potenciálisan kontrollálni tudja az EFT-ben történteket, legalábbis annak tényleges nemzetközi vonatkozásaiban. (Hrubos 2010.)

\section{A 2010-es értékelés}

Az első szakasz értékelésére nehéz, turbulens időkben került sor. A pénzügyi, gazdasági válság hatásai éppen akkor tetőztek a felsőoktatásban. Sokféle megszorítást kellett megtapasztalniuk az intézményeknek, a felsőoktatás minden szereplőjének. A drámai helyzetnek megdöbbentő jelképe volt a Bécs-Budapest helyszíneken megrendezett, a 10 évet lezáró ünnepi rendezvény. Bécs egyetemi hallgatói nagyszabású demonstrációt és más tiltakozó megmozdulásokat rendeztek a Bologna-reform ellen (beleértve az eseményre érkező minisztereket hozó vonat megállítását, a Hofburg körülzárását). A hallgatóknak elsősorban nem tartalmi kifogásaik voltak, hanem az ellen léptek fel, hogy németországi 
hallgatók tömegei érkeztek „váratlanul” az osztrák egyetemekre, miután Németországban bevezették a tandíjat, Ausztriában pedig nem. Mindazonáltal a reform bizonyos gyengeségei álltak a jelenség mögött. Először is az, hogy Bologna kommunikációja kezdettől fogva mindenütt igen erőtlen volt. Kevés információ és késve érkezett el a felsőoktatás szereplőihez. Másrészt itt vált világossá, amit persze elejétől fogva sejteni lehetett volna, hogy a sokféle felsőoktatási rendszert működtető „társulásban” bármely és bárhol történt beavatkozás, változtatás az egész régióra is hatást gyakorolhat. (Hrubos 2016.)

Az értékelések aláhúzták, hogy ebből tanulva a hallgatók társadalmi helyzetének megismerését, a reform szociális hatásait a továbbiakban kiemelt témaként kell kezelni (miközben ez nem szerepelt az eredeti Bologna-feladatok között). A foglalkoztathatóság ügyét a fó Bologna-témák közé kell emelni, hasonlóan az életen át tartó tanulás témájához. Elkerülhetetlen a sokféleség elfogadása, az európai, a nemzeti és az intézményi szint harmóniájára való törekvés.

A gazdasági válság felsőoktatást sújtó hatása felszínre hozta az intézményi autonómia és akadémiai szabadság témáját, amire érzékenyen reagált az EUA. Vizsgálatsorozatot kezdett a témakörben, megteremtve annak elméleti, módszertani hátterét. (Ez a téma is túlmutat az eredeti feladatokon.)

A vállalásokat végül is alapvetően teljesítette az EFT, de a teljesítés szintje igen eltérő az egyes tagállamokban. Új, speciális adatgyüjtési rendszerekre van szükség, és az eredményeket be kell vetni ennek a helyzetnek a reális átlátásához és kezeléséhez. (SursockSmidt 2010.)

\section{A második szakasz - közel 2020-hoz}

A reform második szakaszának kezdetén az EFT-nek rendkívül súlyos kihívásokkal kellett szembenéznie, amelyek jó része később sem enyhült érdemlegesen. A folytatódó gazdasági és szociális válság, a drámai szintű munkanélküliség, a fiatalok növekvő mértékủ marginalizálódása, az aggasztó demográfiai helyzet, az új típusú migráció, szélsőséges megnyilvánulások és a terrorizmus egyaránt konfliktusokat gerjesztettek, megoldandó kérdéseket szültek. Az EFT számára ez azt jelentette, hogy a gyorsan és előre nem látott módon változó környezetben meg kell újítania a 2020-ra megcélzott jövőképét (Hrubos 2016). A 2015-ös jereváni miniszteri találkozó anyagai és a kommüniké a korábban megszokotthoz képest szókimondóbb, kritikusabb, pragmatikusabb hangot ütöttek meg. A kommüniké határozottan kiállt amellett, hogy azokat a strukturális reformokat, amelyekben megállapodtak, ténylegesen be kell vezetni (több tekintetben is késésben vannak egyes országok). (Jereváni kommüniké 2015.) Az EUA által a miniszteri konferenciákra rendszeresen összeállított Trends Report sorozat aktuális száma megállapítja, hogy az EFT kifelé próbálja demonstrálni, hogy van saját felsőoktatás-politikája, miközben a tagországok egyre individuálisabban lépnek fel, nemzeti tradícióikra hivatkozva. Sokféle dinamikus reform zajlott le az országok szintjén, de azok fragmentáltak, széttartóak voltak. Nagyobb aktivitásra lenne tehát szükség az EFT szintjén. Az EUA megfogalmazta jövőképét. Eszerint a fö folyamat a globalizáció és az erőforrásokért folyó verseny további erősödése lesz. Az országok és régiók közötti, valamint az országokon belüli társadalmi, gazdasági különbségek növekednek, ami megnyilvánul a felsőoktatás területén is. A piaci gondolkodás további teret nyer, elmosódnak a határok a magán (private) és az állami (public) között. Az EFT mindeddig szilárdnak 
tűnő alapelve, miszerint a felsőoktatás közjó, átgondolásra szorul. (Sursock 2015; Hrubos 2016.) Jereván jó híre volt, hogy elfogadták a kreditrendszer korrekcióját jelentő ECTS User's Guide 2015 dokumentumot ${ }^{5}$ és a minőségbiztosítás alapelveit tartalmazó ESG-t (European Standards and Gudelines for Quality Assurence in the EHEA 2015). ${ }^{6} 2018$ ban a tagállamok elkezdték bevezetni az új szabályok követését. ${ }^{7}$ Ezzel kapcsolatban került elérhető közelségbe a képzettségek automatikus elismerésének lehetősége (Jerevánban, 2015-ben határoztak erről a miniszterek). Amennyiben a Bologna-eszközök rendben működnek, akkor azok együttesen lehetővé teszik ezt. A fokozatszerzést adó dokumentumot minden további elbírálás nélkül elfogadják a felsőoktatási intézmények, amennyiben további akadémiai fokozatot adó programba kíván valaki belépni (az EFT-n belül). Jelenleg még kevéssé terjedt el ez a gyakorlat a maga teljességében. (Magyarországon még csak részben vannak meg a szabályozási feltételei.) (The European Higher Education Area in 2018: 147-150.)

\section{A szociális dimenzió}

Ebben az évtizedben került kiemelt helyre a hallgatók szociális helyzetének, azon belül a hátrányos helyzetü, sérülékeny rétegek (az ún. alulreprezentált csoportok), a nem tipikus élethelyzetủek (felnőttek) ügye, főleg az ESU kitartó követelései nyomán. Erről a nagyon komplex témáról csak akkor lehet átfogó módon tájékozódni, ha megfelelő adatbázis áll rendelkezésre. (Sursock 2015.) Ennek megvalósítása az EUROSTUDENT projekt keretében valósul meg, aminek megindítását az EB kezdeményezte és támogatja a müködését (további támogató az Erasmus+). Magyarország 2008-tól megfigyelőként, majd 2012 óta teljes jogúként résztvevője a munkának. A legutóbbi 2016-2018 között zajlott, 28 ország vett benne részt (jellemzően azok az EFT-országok a rendszeres résztvevők, amelyek egyben EU-tagok is). A hallgatókat igen széles körü témákban kérdezték meg (pl. pénzügyi helyzete, időgazdálkodása, munkavállalása, nemzetközi mobilitásban való részvétele), és arra vállalkoztak, hogy feltárják mindennek a hátterét (képzési szint, nem, életkor, gyermek, szülők iskolai végzettsége, szubjektív státusz, lakhatás). Az adatbázisnak igen nagy a jelentősége, mivel az oktatáspolitika, a döntéselőkészítés és a szakmai tájékozódás mellett kutatási célra is használható. Ösztönöz az országok közötti összehasonlításra, a projekt résztvevői szakmai hálózatot alkotnak, amelyben folyamatosan magas szintü kollektív munka folyik. (Hámori-Horvátb-Veroszta 2018.) A magyarországi adatok feldolgozásának első szakasza már befejeződött. Az elemzések arra utalnak, hogy a magyar hallgatók helyzete, véleménye általában közepes helyzetet képvisel a nemzetközi összehasonlításban. ${ }^{8}$

\footnotetext{
http://ec.europa.eu/education/ects/users-guide/index_en.htm [Letöltve: 2019. 02. 16.]

https://enqa.eu/index.php/home/esg/ [Letöltve: 2019. 02.16.]

Magyarországon megjelent egy részletesebb útmutató is. Derényi A. \& Simon M. (2016): Tanulásszervezés, tudáselismerés és átjárhatóság a felsőoktatásban. Útmutató az európai kreditrendszer alkalmazásához. Budapest, Oktatáskutató és Fejlesztő Intézet. http://webcache.googleusercontent.com/ search?q=cache:V1aTnGqKVR4J:ofi.hu/sites/default/files/attachments/ects_kotet.pdf $+\& c d=1 \&$ hl=hu $\& \mathrm{ct}=\mathrm{clnk} \& \mathrm{gl}=\mathrm{hu} \& \mathrm{client}=$ firefox-b-d [Letöltve: 2019.02 .16 .]

8 A zárójelentés megtalálható: Social and Economic Conditions of Student Life in Europe. EUROSTUDENT VI 2016-2018 Synopsis of Indicators. http://www.eurostudent.eu/ [Letöltve: 2019. 02. 16.]
} 
Jelenleg folyik egy másik, a felsőoktatást érintő nagy adatgyüjtési projekt előkészítése, amelyet ugyancsak az EB kezdeményezett, ez pedig az EUROGRADUATE, amely lehetőséget biztosít majd, hogy egy sztenderd EFT-adatgyüjtés alapján tájékozódni lehessen a hallgatók munkaerőpiaci kapcsolódásáról, ami alkalmas lesz nemzetközi összehasonlításra is. (Halász 2018.)

\section{A tanulás és tanitás}

A reform második évtizedének emblematikus témája a tanulás és tanítás. A strukturális, szabályozási kérdések után a folyamat végre eljutott a valószínúleg leglényegesebb kérdéshez, a hallgatók és a tanárok szintjéhez. Az EUA felismerte felelősségét, elméleti munkákat folytatott és survey jellegü vizsgálatokat végzett tagintézményei körében. A 2018-as Trends Report foglalta össze a legfrissebb, 2017-es adatgyüjtési hullám eredményeit. Az intézményi stratégia lététől az országos irányításon át a tanítási gyakorlatig és a tanárok továbbképzéséig terjednek a vizsgált témák. A fontos eredmények közé tartozik, miszerint sok helyen már külön szervezeti egység (vagy karonként külön szervezeti egység) foglalkozik a témával, amihez professzionális adminisztratív stáb tartozik, és általában magas szintű egyetemi vezető felügyeli a területet. Ez a kérdés intézményi szintű kiemelt kezelésére utal. Kezd elterjedni az intézményen belül a saját intézményre vonatkozó kutatás. Kutatócsoport dolgozik a stratégiaalkotáson, a tanári szakmai tanácsadásban, valamint végzi a folyamatos monitoringolást. Figyelemre méltó, hogy igen nagy súlyt fektetnek a tanárok továbbképzésére, nagyon tudatos, személyre szabott megoldásokkal. (Gaebel-Zhang 2018.)

Magyarországon az elmúlt tíz évben - jórészt az európai folyamatok hatására - a korábbinál nagyobb érdeklődés irányul a tanulás-tanítás kérdéseire, a minőség javítására. Megjelent a kormányzati figyelem, és konkrét intézkedések is történtek (felsőoktatási stratégia fogalmazódott meg), és a felsőoktatási intézmények is elkezdték önálló stratégiájukat kialakítani a tanulás-tanítás tekintetében. Jelentős előrelépés történt a felsőoktatásra vonatkozó nagy adatbázisok létrehozásában és müködtetésében, ami máris szolgáltat információkat a tényekre alapozott oktatáspolitika és az intézmények számára. A foglalkoztathatóság kérdése, a Bologna-eszközök bevezetése, a képzés hatékonysága és a minőségfejlesztés, a nemzetköziesedés és mobilitás, a tehetséges hallgatók beiskolázása jelzik a müvelt témák sokféleségét. (Derényi 2018.)

\section{A minöségbiztosítás}

A minőségbiztosítás vonalán új fejlemény, hogy már 40 ország tagja az EQAR-nak. Magyarország csatlakozása folyamatban van, és a listára elfogadott ügynökségek száma 44. ${ }^{9}$ A z EQAR kidolgozott egy stratégiát a 2018-2022-es évekre, amit a 2018-as párizsi miniszteri konferenciának küldött meg. Arra kérte az EFT-tag kormányzatokat, hogy mindegyik lépjen be a rendszerbe, mindegyik legyen tagja a kormányzótanácsnak, és az EQAR-ba bejegyzett ügynökségek ítéletét mindannyian automatikusan ismerjék el. Az EQAR információs eszközként fog szolgálni minden érdekelt számára a külső minőségbiztosítás folyamatáról, eredményeiről. (EQAR Message 2018.) A párizsi miniszteri

9 https://www.eqar.eu/ [Letöltve: 2019. 02. 16.] 
konferencia megtárgyalta és elfogadta a javaslatot, elsősorban a Joint Degree programok akkreditációjára való tekintettel (Paris Communiqué 2018). A minőségügy kezelésének centralizálása tehát szabad utat kapott. Ezzel párhuzamosan nyilván csökken az ENQA gyakorlati jelentősége, szerepe elsősorban elméleti és módszertani területen érvényesül majd, ezzel támogatja a minőségbiztosítás professzionalizálódását. Egyébként küszködik azzal a helyzettel, hogy egyes EFT-országokban még mindig hiányosan követik teljességgel az ESG minden pontját a minőségbiztosítás gyakorlatában. (ENQA Message 2018.)

$\mathrm{A} z$ ENQA rendszeresen ellenőrzi a minőségbiztosítási ügynökségek minőségét. A Magyar Felsőoktatási Akkreditációs Bizottság (MAB) a 2013-as értékelés során a „részben megfelelö" besorolást kapta, és a „felülvizsgálat alatt” státuszba tették, mivel nem teljesítette minden tekintetben az ESG-kívánalmakat a függetlenség és az ezzel összefüggő erőforrási standardok tekintetében. Megtörtént a korrekció, és a 2015-ös monitor eljárás azt elfogadta, így megoldódott a kérdés. A 2017-es EFT-jelentés készítése idején tehát már helyreállt a rend. 2018 szeptemberében pedig a szervezet öt évre ismét megkapta az akkreditációt. ${ }^{10}$

\section{Helyzetkép 2018}

Míg a 2015-ös jereváni beszámolót a kritikus hangvétel, a közösen kitűzött feladatok nem teljesítésének számonkérése jellemezte, addig a 2018-as párizsi beszámoló a teljesítések kulturált, de határozott kikényszerítését helyezte kilátásba (az ESU állásfoglalása használja ezt a megfogalmazást) (Bologna with Student Eyes 2018). Ebben nyilván szerepet játszott a ciklus végének közelsége, az az egyértelmü szándék, hogy 2020-ban a kitüzött célok eléréséröl lehessen beszámolni (Paris Communiqué 2018).

A hatalmas és sokféle adatbázisra épülő Jelentés alapvető üzenete az, hogy a Bolognamegvalósítás sokféle konkrét formában és mértékben történt meg, illetve történik. A sokféleség hátterében több különböző tényező áll, amelyek egymás mellett, egyszerre érvényesülnek, így nehéz átlátni ezt a komplexitást. Azonosítható annak a ténynek a hatása, hogy az EFT-országok más-más időpontban csatlakoztak a reformhoz (így megkülönböztethető az 1999-es alapító 29 ország a később érkezőktől). A napóleoni és a humboldti Európa törésvonal „természetesen” most is megnyilvánul, kiegészülve az Észak és a Dél különbségével. Az országok mérete sem elhanyagolható, hiszen igen nagyok a különbségek (több egészen kis lakosságszámú ország is tagja az EFT-nek). A történelmi hatás is megjelenik, pl. a volt szocialista országok speciális vonásaiban. Mindezek a tényezők azonban nem jelennek meg valamilyen közvetlen és domináns magyarázó változóként, hiszen éppen együttes (sokszor egymást keresztező hatásukról van szó). Nagyon sok tehát a „kivétel” a hagyományos (elöítéletes) gondolkodás szemszögéből.

Ebben az összetett mezőnyben a magyar felsőoktatás összességében közepesnek mondható helyzetben van. A legtöbb téma, mutató esetében nagyjából ez látható. Mindazonáltal érdemes felfigyelni azokra a területekre, ahol a kifejezetten jól (legjobban) teljesítők csoportjába került. Ilyen terület elsősorban a hallgatói mobilitás, különösen a Joint Degree tekintetében. Aggodalomra adhat okot viszont, hogy kedvezőtlenek bizonyos alapvető feltételek EFT-viszonylatban. A hallgatói létszám (mint általában a

10 http://www.mab.hu/web/index.php?option=com_content $\&$ view $=$ article $\& i d=468 \&$ Itemid=527\&lang= hu [Letöltve: 2019. 02. 16.] 
volt államszocialista országok esetében) csökkent. Alacsony és csökkenő a 18-34 éves korcsoport részvételi aránya (2015-ben az EFT medián 15,9\% volt, az országok felében növekvő, felében csökkenő, Magyarországon 12,7\%, csökkenő). (The European Higher Education Area 2018: 24-27.) A felsőoktatásra fordított éves költségvetési kiadások mértéke a GDP \%-ában 2014-ben a következő volt: EFT-átlag 1,22\%, nagy a szóródás, a volt államszocialista országokban 1,00\% alatt vannak, Magyarországon pedig 0,77\%. A felsőoktatásra fordított kiadások aránya a közkiadásokon belül 2014-ben 2,8\% volt az EFT átlagában, a volt szocialista országokban 2,00\% alatt, Magyarországon 1,5\%. (The European Higher Education Area 2018: 34-37.)

Mivel a megcélzott „kikényszerítés” ebben a komplexitásban gyakorlatilag nem valósítható meg, a legfontosabb és reálisan korrigálható feladatok esetén ún. scorecardokat (összetett mutatókat) alkottak. Egyértelmű, hogy a kiemelten vizsgált területek a Bologna-eszközök bevezetésének állása és az alulreprezentált csoportok támogatásának kérdése. Olyan témák, amelyek ,jól mérhetők”, hivatalos jogi szabályozáshoz kapcsolhatók. Ezek alapján értékelték az országokat egy 5-ös skálán (az 1-es a legjobb). Érdemes részletesen végigtekinteni, hogy milyen értékelést kapott Magyarország.

1-es értékelés: A megújított oklevélmelléklet bevezetésének állása; A nemzeti képesítési keretrendszer bevezetése; a hallgatók részvételének szintje a külső minőségbiztosítási rendszerben;

2-es értékelés: A külső biztosítási rendszer kiterjedtségének foka; Az alulreprezentált csoportok belépésének támogatása;

3-as értékelés: A nyitottság foka a minőségbiztosítási rendszerben az EQAR felé; $\mathrm{Az}$ előzetes nem formális és informális tanulási eredmények elismerése; Az alulreprezentált csoportok segítésének mértéke tanulmányaik folytatásában és elvégzésében; Az állami hitelek és ösztöndíjak árvihetősége a mobilitás során;

4-es értékelés: $\mathrm{A} z$ akadémiai fokozatok rendszer szintü (automatikus) elfogadása; $\mathrm{Az}$ alulreprezentált csoportok támogatása a nemzetközi mobilitásban;

5-ös értékelés: Az új kreditrendszer bevezetésének ellenőrzése külső minőségbiztosítással; a nemzetközi részvétel szintje a külső minőségbiztosításban. (The European Higher Education Area 2018: 67, 117, 126, 136, 138, 140, 142, 150, 194, 212, 215, 272, 275.)

A miniszterek megállapodtak abban, hogy segítő, tanácsadó csoportot küldenek azokba az országokba, amelyek a scorecardok alapján 4-es vagy 5-ös értékelést kaptak. A „látogatók" akadémiai emberek lesznek, mégpedig azokból az országokból, amelyek viszont az adott területen 1-es, 2-es értékelést értek el (a kiválasztásnál természetesen figyelembe vesznek további szempontokat is.) (Paris Communiqué 2018: Appendix I.) Magyarországon a fentiek alapján két terület (a 4-es és az 5-ös értékelést elérő) tekintetében lehet számítani a „tutorok” jelentkezésére.

\section{A nemzetközi mobilitás komplex kérdése}

A nemzetközi mobilitás témája központi eleme az EU felsőoktatás-politikájának és a Bologna-reformnak is. Az európai integráció egyik legfontosabb vívmánya a felsőoktatási tanulmányok során történő mobilitás, ami megalapozza a későbbi munkahelyi mobilitást is. Az EUROSTUDENT 2017-es vizsgálata kimutatta, hogy több akadályt érzékelnek a hallgatók a mobilitás terén, mint például (az említés csökkenő sorrendjében): a pénzügyi többletteher; a saját intézmény által nyújtott információ hiánya; a külföldi tanulmányok 
elismertetésének problémái; a külföldi tanulmányok nehezen integrálhatók a hazai képzési szerkezetbe; távollét a családtól, partnertől, barátoktól; elégtelen idegennyelv-tudás; a munka elvesztése; korlátozott hozzáférés stb. (Horvátb-Jakab 2018). A téma élesen merül fel, mivel az EFT szereplői folytonosan elégedetlenek a mobilitás mértékének alakulásával a reform eddigi történetében. A 2009-es miniszteri találkozón (Leuven) nyilvánították ki a miniszterek, hogy a cél 2020-ig a 20\%-os mobilitási részvétel a hallgatók körében, ami több ország tekintetében kérdéses.

A mobilitás terén az Erasmus-program viszont igazi sikersztori. A megindítását követő 30 évben összesen 4,5 millió hallgató vett részt a program által támogatott és kezelt, többségében egyszemeszteres mobilitásban (kezdetben csak az EFT-hallgatók, majd a kiterjesztés után más régiók hallgatói is.).

$\mathrm{A} z$ EFT folyamatosan erőfeszítéseket tesz a mobilitásban való részvétel intenzitásának növelésére az akadályok elhárításával. Már müködik az a rendszer, amelyben a tantervekbe eleve beépítenek egy külföldi szemesztert, amit kötelező igénybe venni. A másik megoldás a „mobilitási ablak” kijelölése (egy szemeszterről van szó, amikor külföldre mehet a hallgató, de ez nem kötelező számára. (Vágó 2018.)

\section{Befejezésül}

Mit kapott a magyar felsőoktatás az EU-tagságtól és az EFT-együttműködésből?

Bologna növelte az európai felsőoktatás presztízsét a világ más régióiban, és ebből részesült a magyar felsőoktatás is. A többszintű képzéssel bekerült a világ nagy részében használt rendszerbe, ami segíti a globális mozgást. Kialakult egy európai szintű diskurzus, közös fogalomhasználat, információáramlás, egy szisztematikus gondolkodás a felsőoktatásról, ami így a társadalmi, politikai, szakmai figyelem középpontjába került. A felsőoktatás tartalmát, minden elemét átvizsgálták a reform során, ami segítette, hogy az elavult dolgok lehetőleg lekerüljenek a színről, az átfedések, ismétlődések visszaszoruljanak. Kialakult egy minőségbiztosítási kultúra, ami végső soron a tanulás, tanítás minőségének emelését eredményezte. Magyar szakemberek bekapcsolódtak európai szintű nagy adatbázisok kiépítésébe, kutatási felhasználásába (így az EUROSTUDENT és az EUROGRADUATE projektbe). Végül a magyar hallgatók, az egyetemek akadémiai és adminisztratív stábjának tagjai intenzíven bekapcsolódtak a nemzetközi mobilitási folyamatokba.

\section{IRODALOM}

Bologna with Student Eyes (2018) The Final Count down. European Students' Union (ESU). http://www.ehea.info/cid101765/ministerial-conference-paris-2018.html [Letöltve: 2019. 02. 16.]

Derényi A. (2018) A tanítás és a tanulás minőségének javítása az elmúlt 10 évben. In: Kováts G. \& Temesi J. (eds) A magyar felsőoktatás egy évtizede 2008-2017. NFKK Kötetek 2. Budapest, pp. 130-146. http://nfkk.uni-corvinus.hu/index.php?id=65878 [Letöltve: 2019. 02. 16.]

Derényi A. \& Temesi J. (2008) Kreditrendszer és minőségbiztosítás. Educatio, Vol. 62. No. 1. pp. 64-7. http://www.edu-online.eu/hu/educatio_reszletes.php?id=69 [Letöltve: 2019. 02.16.] 
ENQA Message (2018) to Ministers Responsible for Higher Education in the EHEA 2018. http://www.ehea.info/cid101765/ministerial-conference-paris-2018.html [Letöltve: 2019. 02. 16.]

EQAR Message (2018) to the EHEA Ministerial Conferencein Paris 2018. http://www.ehea. info/cid101765/ministerial-conference-paris-2018.html [Letöltve: 2019. 02. 16.]

Gaebel, M. \& Zhang, Zh. (2018) Trends 18. Learning and Teachingin European Higher Education Area. European University Association. https://eua.eu/resources/ publications/757:trends-2018-learning-and-teaching-in-the-european-higher-educationarea.html [Letöltve: 2019. 02. 16.]

Halász G. (2018) Új vonások az Európai Unió és az OECD felsőoktatással kapcsolatos stratégiájában. In: Kováts G. \& TeMESI J. (eds) A magyar felsőoktatás évtizede 2008-2017. NFKK kötetek 2. Budapest. pp. 25-38. http://nfkk.uni-corvinus.hu/index. php?id=65878 [Letöltve: 2019. 04. 25.]

Hámori Á., Horváth Á. \& Veroszta Zs. (2018) Bevezetés. Az EUROSTUDENT VI kutatás módszertana és tapasztalatai Magyarországon. In: HÁmORI Á. (ed.) Eröforrások, eredmények és élmények a felsőoktatásban. Az EUROSTUDENT VI. nemzetközi hallgatói kutatás magyarországi eredményei. Budapest, Oktatási Hivatal. pp. 13-25. https://www. felvi.hu/pub_bin/dload/felsooktatasimuhely/eurostudent/EUROSTUDENT_VI_ tanulmanykotet_2018.pdf [Letöltve: 2019. 02. 16.]

Horváth Á. \& Jакав A. (2018) Demotivációs tényezők és akadályok mintázatai a nemzetközi hallgatói mobilitásban. In: HÁmori Á. (ed.) Eröforrások, eredmények és élmények a felsőoktatásban. Az EUROSTUDENT VI. nemzetközi hallgatói kutatás magyarországi eredményei. Oktatási Hivatal, Budapest. pp. 78-100. https://www.felvi.hu/ felsooktatasimuhely/EUROSTUDENT/eurostudent_VI_gyorsjelentes [Letöltve: 2019. 04. 25.]

Hrubos I. (2010) Bologna folytatódik. Educatio, Vol. 19. No. 1. pp. 19-33. http://www. hier.iif.hu/hu/educatio_reszletes.php?id=78 [Letöltve: 2019. 02. 16.]

Hrubos I. (2011) A Bologna Piramis. Educatio, Vol. 20. No. 4. pp. 498-508. http://www. hier.iif.hu/hu/educatio_reszletes.php?id=86 [Letöltve: 2019. 02. 16.]

Hrubos I. (2016) Az európai felsőoktatási térség kialakításának második szakasza: helyzetkép félidőben. In: Fenérvári, A., Juhász, E., Kiss, V. Á. \& Kozma, T. (eds) HERA évkönyvek 2015: oktatás és fenntarthatóság. Budapest, Magyar Nevelés- és Oktatáskutatók Egyesülete; Hungarian Educational Research Association. pp. 280-293. http://hera.org. hu/hera-evkonyv-2015/ [Letöltve: 2019. 02. 16.]

Jereváni Kommuniké (2015) http://www.tka.hu/hir/3328/jerevani-kommunike [Letöltve: 2019. 02. 16.]

Kozma T. \& Rébay M (eds, 2008) A bolognai folyamat Közép-Európában. Új Mandátum Könyvkiadó, Budapest.

Paris Communiqué (2018) Paris, May 25th 2018. EHEA Ministerial Conference http:// www.ehea.info/cid101765/ministerial-conference-paris-2018.html [Letöltve: 2019. 02. 16.]

Paris Communiqué (2018) Appendix I. EHEA Ministerial Conference. http://www. ehea2018.paris/ [Letöltve: 2019. 02.16.]

Sursock, A. \& Smidt, H. (2010) Trends 2010: A Decade of Change in European Higher Education. European University Association. https:/eua.eu/resources/ publications/312:trends-2010-a-decade-of-change-in-european-higher-education.html [Letöltve: 2019. 02.16.] 
Sursock, A. (2015) Trends 2015: Learning and Teaching in European Universities. European University Association. http://www.eua.be/Libraries/publications-homepage-list/EUA_ Trends_2015_web [Letöltve: 2019.02.16.]

The European Higher Education Areain 2018. Bologna Process Implementation Report. http://www.ehea.info/cid101765/ministerial-conference-paris-2018.html [Letöltve: 2019. 02. 16.]

VÁGó P. (2018) Erasmus E Co. Bevezetés a hallgatói és oktatói mobilitás világába. Grotius Könyvtár - No. 009. http://www.ehea.info/cid101765/ministerial-conferenceparis-2018.html [Letöltve: 2019. 02. 16.]

A cikk a Creative Commons Attribution 4.0 International License (https://creativecommons.org/licenses/ by/4.0/) feltételei szerint publikált Open Access közlemény, melynek szellemében a cikk bármilyen médiumban szabadon felhasználható, megosztható és újraközölhető, feltéve, hogy az eredeti szerző és a közlés helye, illetve a CC License linkje és az esetlegesen végrehajtott módosítások feltüntetésre kerülnek. (SID_1) 